\title{
PENGARUH EKSTRAK KOPI ROBUSTA TERHADAP EKSPRESI OSTEOKALSIN PADA OSTEOBLAS SELAMA PERGERAKAN GIGI ORTODONTI
}

\author{
Herniyati \\ Fakultas Kedokteran Gigi \\ Universitas Jember \\ Email: herniyati@unej.ac.id
}

\begin{abstract}
The objective of research is to determine the expression of ostocalcin on osteoblasts during orthodontic tooth movement after administration robusta coffee extract. Materials and Methods: 16 rats were divided into 2 groups: group K: rats applied with orthodontic mechanical force (OMF) and group P: OMF + coffee robusta extract of 20mg $/ 100 \mathrm{~g}$ of BW. OMF was conducted by applying ligature wire on permanent maxillary right first molar and both permanent maxillary incisivus. Subsequently, the permanent maxillary right first molar moved to mesial with Ni-Ti orthodontic closed coil spring. Observations were made on day 15 by immunohistochemical examination to determine the expression of osteocalcin. Results: Robusta coffee extract improved the expression of osteocalcin in the compression and tension areas $(p<0.05)$. Expression of osteocalcin in tension area larger than that in compression area $(p<0.05)$. Conclusion: The administration of Robusta coffee extract increases the expression of osteocalcin, which can increase alveolar bone remodeling.
\end{abstract}

Keywords: Alveolar bone remodeling; Orthodontic tooth movement; Osteocalcin; Robusta coffee.

\begin{abstract}
ABSTRAK
Tujuan penelitian adalah untuk mengetahui ekspresi osteocalcin pada osteoblas pada selama pergerakan gigi ortodonti setelah pemberian ekstrak kopi robusta. Bahan dan metode: 16 ekor tikus jantan dibagi menjadi 2 kelompok. Kelompok K: tikus diberikan gaya mekanis ortodonti (GMO) , Kelompok P: diberikan GMO dan ekstrak kopi robusta. sebesar 20mg/100 g BB yang dilarutkan dalam $2 \mathrm{ml}$ aquades. GMO pada tikus dilakukan dengan cara pada gigi molar-1(M-1) rahang atas (RA) kanan dan pada kedua gigi insivus RA diberi kawat ligatur. Kemudian M-1 RA kanan digerakkan ke mesial dengan Niti closed coil spring. Pengamatan dilakukan pada hari ke 15 untuk memeriksa ekspresi osteocalcin dengan metode imunohistokimia .Hasil: pemberian ekstrak kopi robusta meningkatkan ekspresi osteocalcin pada daerah tekanan dan daerah tarikan $(\mathrm{p}<0,05)$. Ekspresi osteocalcin pada daerah tarikan lebih besar daripada daerah tekanan $(p<0,05)$. Kesimpulan: pemberian pemberian ekstrak kopi robusta. efektif meningkatkan ekspresi osteocalcin , sehingga dapat meningkatkan remodeling tulang alveolar.
\end{abstract}

Kata kunci: Kopi robusta; Osteocalcin; Pergerakan gigi ortodonti; Remodeling tulang alveolar. 


\section{PENGANTAR}

Pergerakan gigi yang disebabkan karena aplikasi kekuatan ortodonti tergantung remodeling ligamen periodontal dan tulang alveolar. Remodeling tulang penting untuk pergantian tulang dan terjadi terutama sebagai akibat dari aktivitas osteoklas dan osteoblas (Riancho dan Delgado-Calle, 2011; Tanaka $d k k$., 2005). Aktivitas terkoordinasi dari dua jenis sel ini mengarah ke resorpsi tulang dan deposisi, dalam respon terhadap stres dan beban mekanis (Hadjidakis dan Androulakis, 2006).

Pada sisi tekanan, dengan kekuatan ringan, tulang alveolar langsung diresorpsi oleh osteoklas dalam lakuna Howship. Pada daerah tarikan dengan kekuatan ringan dan berat, tulang diendapkan pada dinding alveolar kemudian terbentuk spikula tulang mengikuti orientasi berkas serat periodontal (Meikle, 2006). Osteoblasts diperlukan untuk meremodeling daerah resorpsi pada daerah tekanan dan membentuk tulang baru pada daerah tersebut dan pada daerah tarikan. Penanda ekspresi gen untuk diferensiasi osteoblas meliputi: alkaline phosphatase, osteokalsin, dan tulang sialoprotein semua terdeteksi pada pemeriksaan imunohistokimia (Kawakami $d k k ., 2004$ ).

Oeteokalsin merupakan matrik protein paling banyak yang terdapat pada tulang. Oeteokalsin diekspresikan oleh osteoblas dan berada dalam matriks tulang selama remodeling tulang alveolar (Hannon dkk., 2006). Oeteokalsin merupakan penyusun 10$20 \%$ protein tulang. Fungsi osteokalsin terkait dengan remodeling tulang, sintesis osteokalsin meningkat karena $1,25(\mathrm{OH})_{2} \mathrm{D}_{3}$ dan dihambat oleh PTH. Osteokalsin disebut juga bone gla protein (BGP), aedalah protein dengan berat molekul rendah yaitu 5,8 kDa, yang merupakan protein non kolagen terbanyak didalam tulang. Sintesis protein ini dipengaruhi oleh vitamin $\mathrm{K}$ dan vitamin $\mathrm{D}$, kedua vitamin ini terlibat dalam pengaturan gen untuk sintesis osteokalsin (Narmada, 2010). Hasil penelitian menunjukkan bahwa pada daerah tarikan dan tekanan menunjukkan ekspresi osteokalsin secara signifikan lebih tinggi bila dibandingkan dengan kontrol, dan pada daerah tarikan ekspresi osteokalsin lebih tinggi daripada pada daerah tekanan dan ekspresi osteokalsin ini mencapai puncaknya setelah dua minggu perlakuan (Garlet $d k k ., 2007$ ).

Kekuatan ortodonti merusak matriks ekstraseluler dan mengaktifkan sel-sel dari jaringan periodontal untuk memfasilitasi pergerakan gigi. Penemuan mechanobiology telah menunjukkan peristiwa seluler dan molekuler yang berurutan, seperti pembangkit sinyal dan transduksi, re-organisasi sitoskeletal, ekspresi gen, diferensiasi, proliferasi, sintesis dan sekresi produk tertentu, dan apoptosis. Ortodontis bekerja di lingkungan biologis yang unik, di mana kekuatan ortodonti yang diterapkan menimbulkan remodeling dari jaringan periodontal yang termineralisasi dan tidak termineralisasi, termasuk pembuluh darah yang terkait dan elemen saraf. Respon mekanis dan inflamasi penting untuk mencapai perpindahan gigi secara klinis. Jika keduanya bekerja, ortodontis bisa mempercepat atau memperlambat pergerakan gigi dengan menambahkan metode adjuvan, baik fisik, kimia, atau bedah (Krisnan and Davidovich , 2009 ).

Pergerakan gigi pada perawatan ortodonti yang memerlukan waktu lama dan biaya perawatan ortodonti yang relatif cukup mahal akan menambah beban ekonomi sehingga upaya untuk mempercepat perawatan ortodonti perlu dilakukan secara terus menerus. Untuk mempercepat pergerakan gigi pada perawatan ortodonti berbagai upaya telah dilakukan antara lain dengan aplikasi lokal PTH, RANKL, osteocalcin, dan prostaglandin (Jianru dkk., 2012).

Kopi merupakan salah satu minuman populer yang dikonsumsi masyarakat. Kopi robusta mengandung kafein dan rata-rata konsumsi kafein yang aman perhari adalah 250-600 mg (Sukendro, 2013). Hasil penelitian menunjukkan bahwa pemberian kafein $50 \mathrm{mg} / \mathrm{kg}$ pada tikus hamil memiliki osteoblas dengan potensi osteogenik yang tinggi yang ditandai dengan peningkatan ekspresi osteokalsin, osteeopontin, sialoprotein, RUNX2, alkali fosfatase dan kolagen tipe satu serta 
peningkatan sintesis nodul mineralisasi (Reis dkk., 2015). Disamping itu kopi juga mengandung chlorogenic acid, phenylalanines yang terbentuk selama proses pemanggangan kopi (Farah dan Donangelo, 2006) dan Caffeic acid yang mempunyai efek sebagai antioksidan yang dapat mengurangi stres oksidatif pada osteoblas (Baek dkk., 2010).

Penelitian ini dilakukanuntuk mengetahui ekspresi osteokalsin pada osteoblas selama pergerakan gigi ortodonti setelah pemberian ekstrak kopi robusta. Diharapkan, jika penelitian ini berhasil dapat dimanfaatkan sebagai terapi untuk mempercepat remodeling tulang sehingga dapat memperpendek waktu perawatan ortodonti, selain efek samping minimal, mudah didapat dan harganya relatif murah.

\section{Bahan dan Metode}

Penelitian ini merupakan penelitian eksperimental laboratories, dengan menggunakan hewan coba tikus wistar jantan dengan rentang usia tiga sampai empat bulan dan berat badan 250-300 gram sebanyak 16 ekor. Tikus dalam keadaan sehat dan dipilih yang memiliki susunan gigi lengkap, kondisi rongga mulut dan jaringan periodontal yang sehat. Tikus dibagi secara acak ke dalam dua kelompok: kelompok kontrol (K): tikus diberikan gaya mekanis ortodonti dan $2 \mathrm{ml}$ aquades dan kelompok perlakuan $(\mathrm{P})$ : tikus diberikan gaya mekanis ortodonti dan ekstrak beku kering (freeze dried extract) kopi Robusta sebesar 20mg/100 g BB ( setara dengan satu cangkir kopi orang dewasa) yang dilarutkan dalam $2 \mathrm{ml}$ aquades. Gaya mekanis ortodonti pada tikus dilakukan dengan cara tikus di anestesi menggunakan ketamin, kemudian gigi molar-1 (M-1) rahang atas (RA) kanan dan pada kedua gigi insivus RA diberi kawat ligatur dengan diameter 0,20 mm. Selanjutnya gigi M-1 RA kanan digerakkan ke mesial menggunakan Tension Gauce untuk menghasilkan kekuatan $10 \mathrm{~g} / \mathrm{cm}^{2}$ dengan Nickel Titanium Orthodontic closed coil spring panjang $6 \mathrm{~mm}$ (D'Apuzzo et al.,2013). Pengamatan dilakukan dengan cara tikus dikorbankan pada hari ke 15 dan diambil gigi M1-1 dan M-2 RA kanan beserta jaringan periodontalnya. Selanjutnya dilakukan pemeriksaan imunihistokimia untuk menentukan ekspresi osteokalsin pada osteoblas Data ekspresi osteokalsin pada osteoblas dianalisis dengan menggunakan Student't-test, paired t-test dan Mann-Whitney Test dengan tingkat kepercayaan $95 \%(\alpha=0,05)$.

\section{HASIL DAN PEMBAHASAN}

Pergerakan gigi ortodonti diperoleh dari remodeling ligamen periodontal dan tulang alveolar dalam menanggapi beban mekanis, merupakan proses yang berkelanjutan dan seimbang ditandai oleh deposisi tulang pada daerah tarikan dan resorpsi pada daerah tekanan tulang (Garlet dkk., 2007).

Kekuatan ortodonti mengubah aliran darah dan lingkungan elektrokimia lokal dalam ruang periodontal. Perubahan tibatiba ini menyebabkan generasi dan propagasi dari kaskade sinyal yang terkait remodeling jaringan melalui reaksi biokimia dan seluler yang terjadi pada jaringan yang mengalami mineralisasi (tulang alveolar) dan jaringan yang tidak mengalami mineralisasi (periodonsium). Beberapa biomarker mewakili modifikasi biologis ini diekspresikan selama fenomena tertentu, yaitu, proses inflamasi, resorpsi dan pembentukan tulang, perubahan ligamen periodontal, dan respon pembuluh darah dan saraf (Brooks dkk., 2009).

Osteokalsin merupakan salah satu marker/penanda ekspresi gen untuk diferensiasi osteoblas (Kawakami $d k k$., 2004). Selama pergerakan gigi ortodonti, tulang baru terbentuk pada daerah tarikan. Osteoblas berdiferensiasi dari perkursor sel mesenchymal. Osteoblas dewasa membentuk osteoid diikuti proses mineralisasi (Sprogar, 2008).

Kopi adalah salah satu sumber utama antioksidan dalam diet sehari-hari masyarakat. Efek kesehatan yang menguntungkan dari kopi biasanya dikaitkan dengan aktivitas antioksidan yang tinggi (kemampuan untuk menghambat proses oksidasi). Banyak publikasi memberikan perbandingan aktivitas antioksidan dalam minuman populer seperti kopi, teh, dan kakao (Yashin $d k k ., 2013)$. 
Hasil penelitian ekspresi osteokalsin setelah pemberian ekstrak kopi Robusta ditunjukkan pada Tabel 1. Hasil pemeriksaan imunohistokimia ekspresi osteokalsin pada sel osteoblas pada daerah tekanan dan daerah tarikan ditunjukkan pada Gambar 1.

Tabel 1.

Rerata \pm Simpang baku ekspresi osteokalsin dan hasil uji beda antar kelompok penelitian pada daerah tekanan dan daerah tarikan

\begin{tabular}{|c|c|c|c|c|}
\hline \multirow{2}{*}{ Kelompok } & \multirow[b]{2}{*}{$\mathbf{n}$} & \multicolumn{2}{|c|}{ Osteocalcin (Rerata \pm Simpang baku ) } & \multirow[b]{2}{*}{$\mathbf{p}$} \\
\hline & & Daerah Tekanan & Daerah Tarikan & \\
\hline Kontrol (K) & 8 & $3,25 \pm 1,035$ & $3,50 \pm 0,535$ & $0,598^{* * *}$ \\
\hline Perlakuan $(\mathrm{P})$ & 8 & $9,00 \pm 1,195$ & $12.75 \pm 1,488$ & $0,001^{* * *}$ \\
\hline \multicolumn{2}{|l|}{$\bar{p}$} & $0,000^{*}$ & $0,000^{* *}$ & \\
\hline
\end{tabular}

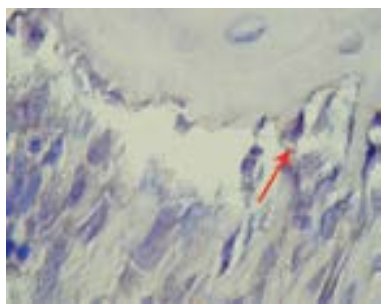

Kel. Kontrol (K)

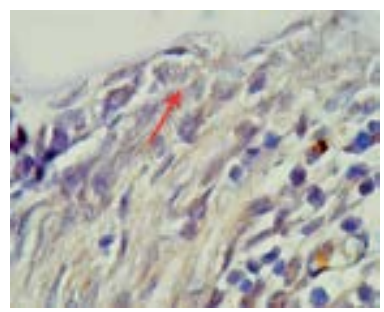

Kel. Perlakuan (P)

Daerah Tekanan

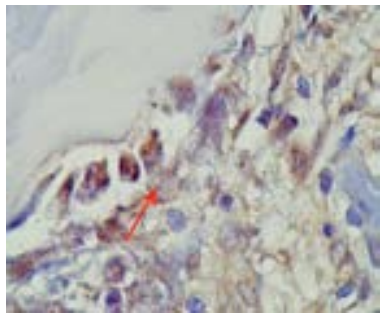

Kel. Kontrol (K)

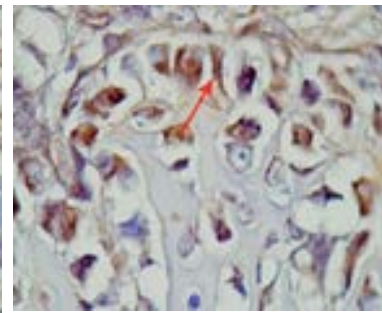

Kel. Perlakuan (P) Daerah Tarikan

Gambar 1.

Ekspresi osteokalsin pada osteoblas daerah tekanan dan daerah tarikan tulang alveolar tikus pada kelompok Kontrol (K) dan Perlakuan (P)

Pemberian ekstrak beku kering kopi Robusta pada hari ke-15 menunjukkan terjadi peningkatan ekspresi osteokalsin pada osteoblas pada daerah tekanan maupun daerah tarikan dan osteokalsin pada daerah tarikan lebih besar daripada daerah tekanan. Hal Ini disebabkan karena kafein yang terkandung pada kopi meningkatkan diferensiasi osteoblas dengan mengikat reseptor adenosin dan memodulasi beberapa reseptor lain termasuk reseptor glukokortikoid, insulin, estrogen, androgen, vitamin D, cannabonoid, glutamat, dan reseptor adrenergik yang semuanya diekspresikan dalam osteoblas (Reis $d k k ., 2015)$. Ini juga sesuai dengan hasil penelitian sebelumnya menunjukkan bahwa kafein dengan konsentrasi 0,1 mM ini dengan adipose tissue-derived stem cells (ADSCs) dan sel-sel stroma sumsum tulang, meningkatkan diferensiasi osteoblas; yang dimediasi melalui aktivasi Runx2 (Jem $d k k$., 2013).

Di samping itu, kopi mengandung caffeic acid yang merupakan phenolic acids golongan non-flavonoids, mempunyai efek sebagai antioksidan yang dapat mengurangi stres oksidatif pada osteoblas (Baek $d k k$., 2010). Aktivitas antioksidan penting dalam merangsang aktivitas osteoblastik melalui reseptor spesifik (Banfi $d k k$., 2008), sehingga osteocalcin yang dihasilkan juga meningkat. Ekspresi osteocalcin pada daerah tarikan lebih besar daripada daerah tekanan ini sesuai dengan hasil penelitian sebelumnya yang menunjukkan bahwa pemberian kopi robusta juga jumlah osteoblas pada daerah tarikan lebih besar daripada daerah tekanan (Herniyati, 2015). 
Hal ini juga ditunjang dengan hasil penelitian sebelumnya yang menunjukkan bahwa Chlorogenic acid mempromosikan osteogenesis pada human adipose tissue derived mesenchymal stem (hAMSCs), yang ditunjukkan dengan peningkatan mineralisasi. Tingkat mRNA dari alkaline phosphatase dan faktor transkripsi Runx-2 yang diperlukan untuk diferensiasi osteoblas meningkat secara signifikan.setelah pemberian $30 \mathrm{pM}$ Chlorogenic acid (Bin dkk., 2013), sehingga jumlah osteoblas dan ekspresi osteokalsin juga mengalami peningkatan.

\section{SIMPULAN}

Hasil analisis data dan pembahasan dalam penelitian ini dapat disimpulkan bahwa pemberian ekstrak kopi robusta efektif meningkatkan ekspresi osteokalsin pada daerah tekanan dan daerah tarikan. Ekspresi osteokalsin pada daerah tarikan lebih besar daripada daerah tekanan. Dengan demikian pemberian ekstrak kopi robusta dapat dijadikan alternatif untuk mempercepat proses remodeling tulang dan pergerakan gigi ortodonti sehingga dapat mempercepat perawatan ortodonti.

\section{UCAPAN TERIMAKASIH}

Penulis mengucapkan terimakasih pada ketua bagian biomedik Fakultas Kedokteran Gigi Universitas Jember dan pengelola laboratorium biokimia Fakultas Kedokteran Universitas Brawijaya Malang dalam perlakuan pada hewan coba dan proses pemeriksaan imunohistokimia.

\section{DAFTAR PUSTAKA}

Baek, K.H., Oh, K.W., Lee, W.Y., Lee ,S.S., Kim, M.K. and Kwon, H.S. 2010. Association of oxidative stress with postmenopausal osteoporosis and effects of hydrogen peroxide on osteoclast formation in human bone marrow cell cultures. Calcif Tissue Internat. 87 (3): 226-35.

Banfi, G., Iorio, E. L. and Corsi, M.M. 2008. Oxidative stress, free radicals and bone remodeling. Clinical Chemistry and Laboratory Medicine: CCLM/ FESCC 46(11): 1550-1555.
Bin, H.S., Jeong, J. H. and Choi, U. K. 2013. Chlorogenic acid promotes osteoblastogenesis in human adipose tissue-derived mesenchymal stem cells. Food Science, and Biotechnology 22: 107-112.

Brooks, P.J., Nilforoushan, D., Manolson, M. F., Simmons, C, A. and Gong, S.G. 2009. Molecular markers of early orthodontic tooth movement. Angle Orthodontis 79( ): 1108-1113.

D’Apuzzo , F., Cappablanca , S., Clavarella, D., Monsurro, A., Biavati, A.S. and Perillo, L. 2013.. Biomarkers of Periodontal Tissue Remodelling during Orthodontic Tooth Movement in Mice and Men, Overview and Clinical Relevance, Scien.World J.

Farah, A. and Donangelo, C.M. 2006. Phenolic compounds in coffee. Braz. J. Plant Physiol. 18: 23-36.

Jem, S. S., Lung, C. K., Hui, S. S., Tsung, Y.Y., Wen, S.H. and Ming, C. K. 2013. Caffeine regulates osteogenic differentiation and mineralization of primary adipose-derived stem cells and bone marrow stromal cell line. International Journal of Food Sciences and nutritionl 64(4): 429-436.

Jianru, Y., Zhang, L.,, Yan, B., Yang, L., Li, Y. and Zhao, Z. 2012. Drinking coffee may help accelerate orthodontic tooth movement. Department of Dental Implants, State Key Laboratory of Oral Diseases, West China Stomatology Hospital, Sichuan University, Chengdu, Sichuan, China, 3(2): 72-75.

Garlet, T.P., Coelho, U., Silva, J.S. and Garlet, G.P. 2007. Cytokine expression pattern in compression and tension sides of the periodontal ligament during orthodontic tooth movement in humans. Europ J of oral Sciences 115( 5): 355-362.

Hadjidakis, D.J. and Androulakis, I.I. 2006. Bone remodeling. Annals of the New 
York Academy of Sciences 1092: 385-396.

Hannon, R,A. and Eastell, R. 2006. Bone markers and current laboratory assays. Cancer Treatment Review 32(1): 7-14.

Kawakami,M.and Yamamoto,T.T.2004.Local injection of 1,25-dihydroxyvitamin D3 enhanced bone formation for tooth stabilization after experimental tooth movement in rats. J Bone Miner Metab 22: 541-546.

Krisnan, V. and Davidovitch, Z. 2009. The role of tumor necrosis factor type 1 in orthodontic tooth movement. J Dent Res 88(7): 597-608.

Meikle, M.C. 2006. The tissue, cellular, and molecular regulation of orthodontic tooth movement: 100 years after Carl Sandstedt. Eur J Ortho ;28(3): 221240.

Narmada, I.B. 2010. Efek Biostimulasi Laser Intensitas Rendah Terhadap Kecepatan Pergerakan GigiOtodonti. Disertasi. Prodram Pasca Sarjana Universitas Airlangga. Surabaya.

Reis, A.S., Riberio, L.G.R., Ocarino, N. M., Goes, A.M. and Serakides, R. 2015.
Osteogenic potential of osteoblasts from neonatal rats born to mothers treated with caffeine throughout pregnancy. BMD Musculoskeletal Disorders 16: 10.

Riancho, J.A. and Delgado-Calle, J. 2011. Osteoblast-osteoclast interaction mechanisms. Reumatología Clínica 2: S1-S4.

Sprogar, S., Vaupotic, T., Cor, A. and Drevensek G. 2008. The endothelin system mediates bone modeling in the late stage of orthodontic tooth movement in rats. Bone 43(4): .740747.

Sukendro ,S. 2013. Keajaiban Dalam Secangkir Kopi. Penerbit Media Pressindo. Yogyakarta.

Tanaka, Y., Nakayamada, S. and Okada, Y. 2005. Osteoblasts and osteoclasts in bone remodeling and inflammation. Current Drug Targets Inflammation and Allergy 4: 325-328.

Yashin, A., Yashin, Y., Wang, J. Y. and Nemzer, B. 2013. Antioxidant and Antiradical Activity of Coffee. Antioxidants 2: 230-245. 